\title{
PENGARUH CITRA MEREK, KEMUDAHAN TRANSAKSI DAN LOKASI TERHADAP KEPUTUSAN MENJADI ANGGOTA KOPERASI SYARIAH BMT BISMA TANGERANG
}

\author{
Nur Jamaludin \\ Rohadatul A'is \\ Sekolah Tinggi Ekonomi Syariah Islamic Village Tangerang \\ Email: nurjamaludin@gmail.com, rohadatulais164@gmail.com
}

\begin{abstract}
This study aims to determine the effect of brand image, ease of transaction and location on the decision to become a member of the Sharia Cooperative BMT BISMA Kelapa Dua Tangerang. This study took the population of members of the BMT BISMA Kelapa Dua Sharia Cooperative with purposive sampling technique. The method used is descriptive quantitative by conducting statistical tests consisting of validity, reliability, classical assumption tests, multiple regression tests and hypothesis testing by testing brand image variables, transaction convenience and location partial or simultaneous influence on the decision. The findings of this study indicate that the ease of transaction and location variables have a positive and significant influence on the decision to become a member of the BMT BISMA Sharia Cooperative. While the brand image variable does not have a significant influence on the decision to become a member of the BMT BISMA Sharia Cooperative.
\end{abstract}

Keyword: Brand image, transaction convenience, location, and decision

\section{PENDAHULUAN}

Indonesia memiliki penduduk mayoritas beragama Islam dimana jumlah penduduk muslim sebanyak $87,2 \%$ dari total jumlah penduduknya. dengan banyaknya jumlah penduduk muslim seharusnya di Indonesia menjalankan setiap ativitas salah satunya dalam bidang ekonomi dilakukan berdasarkan prinsipprinsip syariah. termasuk juga dalam sistem keuangan di Indonesia mulai dari perbankan maupun lembaga intermediasai keuangan lainnya seharusnya menerapkan nilai keislaman. Afandi dan Amin, (2018).

Secara umum lembaga keuangan memiliki fungsi sebagai lembaga intermediasi atau sebagai pelantara bagi yang memiliki uang dan yang membutuhkan uang, serta lembaga keuangan ini dapat meberikan layanan dalam bentuk simpanan dan pembiayaan kepada masyarakat yang kekurangan dana dalam bentuk pinjaman. Indonesia memiliki sistem lembaga keuangan yang terdiri dari dua sistem, pertama sistem lembaga keuangan konvensional dan sistem lembaga keuangan syariah (LKS). Dalam menjalankan usahanya lembaga keuangan konvensional lebih mengutamakan sistem bunga. Sedangkan sedangkan lembaga keuangan syariah lebih mengutamakan sistem bagi hasil dalam menjalankan usahanya. Nafiah, (2018).

Berdasarkan lembaga keuangan non bank syariah yang disebutkan diatas salah satunya koperasi Syariah dimana lembaga ini bagian dari salah satu lembaga intermediasi nonbank yang menyimpan uang dan memberikan pembiayaann kepada masyarakat yang memerlukan pembiayaan. Dalam perkembangan koperasi dapat dilihat dari seluruh jumlah anggota koperasi yang ada di Indonesia. 
Menurut Kementerian Koperasi dan Usaha Kecil Menengah Republik Indonesia perkembangan jumlah anggota koperasi di Indonesia menurun hal tersebut dilihat dari tahun 2016 ke tahun 2017 jumlah anggota meningkat sampai 6.386 .267 orang, sedangkan ditahun selanjutnya pada tahun 2018 mengalami penurunan, tercatat ditahun 2018 peningkatan jumlah anggota koperasi hanya sebanyak 1.821 .313 orang. Sedangkan di tahun 2019 peningkatan jumlah anggota koperasi sebanyak 2.413.743 orang. Penurunan jumlah anggota koperasi disebabkan kendalakendala yang dihadapi koperasi itu sendiri mulai dari sistem maupun operasional dari koperasi.

Berdasarkan perkembangannya Koperasi Syariah BMT BISMA sejak di dirikan pada tahun 2012 sampai dengan sekarang untuk jumlah anggotanya hanya sebanyak 1.283 orang. Andy (2020). Hal tersebut berbanding terbalik dengan salah satu koperasi Syariah terbaik di Tangerang yaitu Koperasi Syariah Benteng Mikro Indonesia yang memiliki jumlah anggota sebanyak 190.988 orang. Koperasi Syariah BMI (2021). Berdasarkan perbandingan antara jumlah Koperasi Syariah BMT BISMA dengan Koperasi Syariah Benteng Mikro Indonesia memiliki jumlah perbedaan yang cukup jauh hal ini dapat disebabkan beberapa faktor yang menyebabkan jumlah anggota antara koperasi syariah tersebut berbeda jauh.

Masyarakat kurang tertarik untuk menjadi anggota koperasi Syariah BMT BISMA ketika citra merek yang buruk hal ini dapat disebabkan rendahnya manfaat citra merek yang dirasakan anggota sehinngga masyarakat kurang percaya terhadap produk yang ditawarkan oleh koperasi syariah. Selanjutnya produk yang ditawarkan koperasi syariah BMT BISMA belum dapat mengatasi permasalahan yang dihadapi oleh anggota. Kemudian kurang populernya produk-produk koperasi syariah BMT BISMA dibandingkan dengan koperasi syariah lainnya, menyebabkan masyarakat lebih memilih koperasi yang telah dikenal oleh masyarakat. kurang populernya koperasi syariah disebabkan masih belum optimalnya promosi yang dilakukan oleh koperasi syariah sehingga persepsi citra merek menjadi buruk.

Faktor selanjutnya yaitu kemudahan transaksi, hal ini berkaitan dengan lamanya proses transaksi pada koperasi syariah BMT BISMA salah satunya dalam hal transaksi pembiayaan dimana memerlukan waktu selama satu minggu untuk mengajukan pembiayaan, sering terjadi proses dalam pengajuan pembiayaan membutuhkan waktu yang lama hal ini disebabkan oleh prosedur yang harus dilaksanakan mulai dari pendaftaran, banyaknya persyaratan yang harus dipenuhi, sampai dengan survei yang dilakukan oleh petugas koperasi untuk menentukan layak atau tidak anggota koperasi syariah mendapatkan pembiayaan, sehingga masyarakat kurang berminat untuk menjadi anggota koperasi, selanjutnya mayoritas koperasi syariah tidak memiliki vasititas yang mudah untuk melakukan transaksi pada koperasi semuanya kebanyakan manual, sehingga masyarakat memilih lembaga intermediasi lain untuk memenuhi kebutuhannya.

Pemilihan lokasi koperasi syariah yang kurang strategis menyebabkan masyarakat tidak mengetahui jika terdapat koperasi syariah dilingkungan sekitarnya. Dalam menentukan lokasi usaha perlu memperhatikan beberapa faktor seperti kemudahan akses menuju lokasi yang dapat dijangkau dengan transportasi umum, kemudian visabilitas dimana lokasi tersebut dapat terlihat dengan jelas pada jarak mata normal, setelah itu tempat parkir yang luas, nyaman dan aman, dan ketersediaan lahan kosong disekitar lokasi yang akan dijadikan tempat koperasi syariah yang memudahkan untuk memperluas bangunan dikemudian hari.

Faktor lainnya yang dapat mempengaruhi keputusan menjadi anggota 
yaitu lokasi, dimana lokasi menjadi faktor yang dapat mempengaruhi anggota disebabkan jauh dekatnya jarak rumah anggota dengan lokasi dari koperasi syariah serta kemudahan untuk menjangkau oleh kendaraan. Maka dangan ini sangat perlu untuk diperhatikan dalam pemilihan lokasi yang mudah dijangkau akan menarik masyarakat untuk ikut dalam keanggotaan koperasi syariah. Untuk lokasi dari Koperasi Syariah BMT BISMA Kelapa Dua sendiri berada di dalam perumahan kelapa dua sehingga tidak dapat diakses oleh transportasi umum, lokasi tempat parkir yang hanya dapat menampung kendaraan roda dua dan tidak dapat melakukan ekspansi karena koperasi syariah berdekatan dengan rumah warga perumahan kelapa dua.

Berdasarkan latar belakang dan penjelasan di atas maka tujuan penelitian ini untuk mengetahui pengaruh citra merek, kemudahan transaksi dan lokasi sehingga memutuskan untuk jadi anggota operasi syariah dengan mengambil studi kasus pada Koperasi Syariah BMT BISMA Kelapa Dua Tangerang Banten.

\section{LANDASAN TEORI}

\section{Citra Merek}

Menurut Chalida (2018). Citra merek adalah salah satu bagian dari asosiasi yang timbul pada benak konsumen pada saat melihat maupun mengingat suatu brand tertentu. Asosiasi tersebut secara otomatis dapat muncul difikiran konsumen dalam bentuk pandangan maupun citra baik buruk suatu merek tertentu.

Citra merek merupakan penilaian masyarakat tentang baik buruknya nama sutu produk maupun perusahaan yang muncul dari produk maupun jasa yang ditawarkannya.

Berikut ini indikator citra merek menurut Biel dalam skripsi Nuri (2020): 1). Citra Pembuat; Citra merek yang baik itu belum tercipta maka perusahaan akan memberikan dorongan dengan meningkatkan kualitas produk maupun yang lainnya. 2). Citra Pemakai; Citra pakai tercipta oleh masyarakat yang telah menggunakan suatu merek secara terus menerus dan berkelanjutan. 3). Citra Produk; Salah satu alasan masyarakat menggunakan produk maupun jasa yaitu untuk memenuhi kebutuhannya, maka baik buruknya citra suatu produk akan dinilai oleh masyarat setelah menggunakan produk maupun jasa yang digunakannya.

\section{Kemudahan Transaksi}

Menurut Lestari dan Iriani, (2018) kemudahan merupakan suatu tahapan dimana sesorang konsumen atau pengguna yakin penggunaan teknologi atau sistem dapat mudah untuk digunakan dan dapat meminimalisir kesalahan. Menurut Turban kemudahaan transaksi merupakan suatu tahapan untuk mencapai sesuatu dengan cara yang mudah tanpa mempersulit konsumen yang menggunakan produk atau jasa tersebut pada saat menggunakan maupun proses transaksinya.

Kemudahan transaksi merupakan suatu proses untuk mendapatkan suatu barang maupun jasa yang diinginkan dengan melalui proses yang cepat dan persyaratan yang mudah dalam transaksi untuk memperolehnya.

Berikut ini indikator kemudahan transaksi menurut Lestari dan Iriani, (2018), adalah: 1). Kemudahaan dipahami. 2). Kemudahan pembayaran. 3). Pilihan transaksi yang dapat disesuaikan

\section{Lokasi}

Menurut Marendra, (2018). Lokasi merupakan tempat kegiatan seluruh operasional dari perusahaan yang dilakukan stafnya, penentuan lokasi ini dilakukan guna mempermudah saluran distribusi serta memudahkan penyampaian jasa kepada calon konsumen.

Lokasi merupakan suatu tempat yang dipergunakan untuk usaha oleh seseorang 
atau kelompok orang, dimana tempat tersebut dipergunakan untuk kegiatan operasional dari perusahaan mulai dari memproduksi suatu barang, memberikan pelayanan jasa mapuan yang lainnya kepada konsumen dengan harapan dapat meciptakan nilai ekonomi dan keuntungan.

Menurut Tjiptono dan Chandra dalam Harahap, (2018), penentuan lokasi fisik harus dipertimbangkan dengan cermat, maka perlu diperhatikan beberapa indikator antara lain: 1). Akses, dimana tempat kopersi syariah tersebut mudah untuk akses oleh transportasi umum. 2). Visabilitas, dimana tempat koperasi Syariah secara fisik dapat dilihat secara jelas oleh jarak pandang normal. 3). Lalulintas, dimana dapat dilihat dari banyaknya orang yang melewati lokasi tersebut sehingkat dapat memungkinkan masyarakat tertarik untuk ikut serta dalam keanggotaan koperasi syariah. 4). Tempat parkir yang luas dan nyaman untuk kendaraan roda dua mapun roda empat. 5). Ekspansi, terdapat lahan yang luas disekitar lokasi koperasi syariah sehingga dapat memungkinkan untuk memperluas kantor dikemudian hari. 6). Lingkungan, kondisi sekitar koperasi yang sesuai dengan jasa yang ditawarkan oleh koperasi syariah.

\section{Keputusan}

Menurut Stoner dalam Nafiah, (2018). Pengambilan keputusan adalah suatu proses pemilihan tindakan dalam satu arah untuk cara pemecahan suatu masalah tertentu. Pengambilan keputusan merupakan proses tahapan berfikir seseorang untuk menemukan solusi dari masalah yang sedang dihadapinya.

Pengambilan keputusan adalah suatu proses berfikir seseorang serta kegiatan pencarian data dan fakta guna untuk menjawab permasalahan yang dihadapinya serta untuk mementukan keputusan yang akan diambil dari pilihan-pilihan tersebut.

Menurut Bei dan Chiao dalam Pardede dan Haryadi, (2017). Indikator dalam pengambilan keputusan antara lain:
1). Keputusan Membeli. 2). Kecocokan terhadap produk. 3). Pembelian kembali. 4). Tingkat ingin merekomendasikan.

\section{METODE PENELITIAN}

Metode yang digunakan pada penelitian ini kuantitatif deskriptif adalah penelitian dalam bentuk angka-angka yang selanjutnya diberikan penjelasan terhadap data-data yang telah didapatkan. Yang bertujuan untuk mengetahui pengaruh citra merek, kemudahaan transaksi dan lokasi terhadap keputusan menjadi anggota Koperasi Syariah BMT BISMA Kelapa Dua, Kabupaten Tangerang.

Penelitian ini mengambil populasi para anggota Koperasi Syariah BMT Bisma Kantor Cabang Kelapa Dua Tangerang. Untuk jumlah keseluruhan anggota koperasi Syariah BMT BISMA sebanyak 1.283 orang sedangkan yang dijadikan populasi dalam penelitian ini berdasarkan kriteria yang telah ditetapkan maka populasi dalam pengambilan sampel sebanyak 105 orang untuk anggota koperasi syariah baru masuk pada tahun 2020. Dan Teknik pengambilan sampel yaitu dengan menggunakan purposive sampling yaitu suatu jenis teknik pengambilan sample nonprobability sampling dengan cara menentukan sampel berdasarkan kriteria-kriteria yang digunakan oleh peneliti. Hardani, et al, (2020).

Dengan kriteria responden dalam peneltian ini para anggota Koperasi Syariah BMT BISMA Kelapa Dua Tangerang yang masih aktif dalam keanggotaan dan ikut serta keanggotaan pada tahun 2020. dan perhitungannya menggunakan rumus slovin dengan nilai signifikan sebesar 0,05 atau $5 \%$. Berikut perhutungan jumlah sampel dengan menggunakan rumus slovin. Berdasarkan hasil perhitungan dengan menggunakan rumus slovin dengan ketentuan jumlah populasi sebanyak 105 orang maka didapatkan jumlah sampel sebanyak 83 orang. 


\section{HASIL PENELITIAN} PEMBAHASAN

\section{Hasil Penelitian}

\section{Uji validitas}

Menurut Hardani, et al, (2020). Uji validitas ini salah satu bagian yang penting dari penelitian karena pengujian validitas ini dapat menjamin keabsahan dalam pengukuran penelitian yang dilihat dari butir-butir pernyataan yang telah ditentukan sesuai dengan variabel yang digunakan untuk menentukan hubungan suatu fenomena.

Berdasarkan hasil uji korelasi dapat dilihat bahwa nilai $r$ tabel yang telah didapatkan sebesar 0,2159 maka dapat dilihat seluruh butir pernyataan dari 83 responden dinyatakan seluruh butir pernyataan yang ada pada kuesiner valid serta dapat digunakan pada penelitian serta dapat dilanjutkan dalam pengolahan data ketahap selanjutnya karena nilai $r$ hitung lebih besar dari nilai $r$ tabel.

\section{Uji reliabilias}

Tujuan uji ini untuk melihat kehandalan suatu pernyataan yang diberikan kepada responden, maksud dari kehandalan yaitu jawaban yang dierikan oleh responden selalu konsisten jika ditanyakan berulang-ulang akan memberkan jawaban yang sama. Nafiah (2018).

Tabel 1: Uji Reliabilitas

\begin{tabular}{lccc}
\hline \multicolumn{1}{c}{ Variabel } & Cronbach's Alpha & R tabel & Keterangan \\
\hline Citra Merek & 0,788 & 0,2159 & Reliabel \\
Kemudahan Transaksi & 0,787 & 0,2159 & Reliabel \\
Lokasi & 0,777 & 0,2159 & Reliabel \\
Kepuasan & 0,769 & 0,2159 & Reliabel \\
\hline
\end{tabular}

\section{Sumber: Data Primer, tahun 2021}

Berdasarkan tabel 1, hasil uji reliabilitas dapat dilihat seluruh nilai Cronbach's Alpha pada setiap variabel yang diteliti lebih besar dari nilai $r$ tabel yang sebesar 0,2159. Serta nilai dari Cronbach's Alpha lebih dari 0,70. Jadi dapat disimpulan seluruh variabel dinyatakan reliabel dan dapat digunakan dalam penelitian.

\section{Analisis regresi linear berganda}

Tujuan regresi berganda ini untuk mengetahui pengaruh variabel citra merek, kemudahan transaksi dan lokasi terhadap variabel keputusan menjadi anggota Koperasi Syariah BMT BISMA, selain itu regresi berganda ini akan melihat bagaimana jika nilai variabel independen nilainya dinaikan 1 satuan. Saripah (2016).

Tabel 2: Pengaruh Citra Merek, Kemudahan Transaksi dan Lokasi Terhadap Kepuasan

\begin{tabular}{lcccccc}
\hline & \multicolumn{6}{c}{ Parameter } \\
\cline { 2 - 7 } \multicolumn{1}{c}{ Variabel } & $\begin{array}{c}\text { Mult. } \\
\text { R }\end{array}$ & $\begin{array}{c}\text { R } \\
\text { Square }\end{array}$ & Konstanta & $\begin{array}{c}\text { Koefisien } \\
\text { Regresi }\end{array}$ & Sig. & $\boldsymbol{\alpha}$ \\
\hline Citra Merek & & & & 0,256 & 0,069 & \\
Kemudahan_- & - & 0,719 & 1,737 & 0,884 & 0,000 & 0,05 \\
Transaksi & & & & 0,182 & 0,012 & \\
Lokasi & & & & & &
\end{tabular}

Keterangan: Variabel Kepuasan

Sumber: data diolah 2021 
Berdasarkan tebel 2, nilai $R$ Square memiliki nilai 0,719 hal ini menujukan citra merek, kemudahan transaksi dan lokasi berkontribusi sebesar $71,9 \%$ sedangkan sisanya $28,1 \%$ variabel lain yang tidak diteliti pada penelitian ini.

Berikut ini persamaan regresi linier berganda yang dapat diketahui dari hasil perhitungan yang diperoleh dari tabel coefficients dalam penelitian ini.

\section{$Y=1,737+0,256 X_{1}+0,884 X_{2}+0,182 X_{3}$}

Berdasarkan persamaan regresi diatas dapat disimpulan antara lain sebagai berikut: Nilai koefisien regresi citra merek memiliki nilai 0,256 hal ini berarti apabila citra merek mengalami peningkatakn maka maka keputusan menjadi anggota koperasi Syariah akan meningkat, dengan asumsi kemudahan transaksi dan lokasi tetap. Nilai koefisien regresi kemudahan transaksi memiliki nilai 0,884 hal ini berarti apabila kemudahan transaksi mengalami peningkatakn, maka keputusan menjad anggota koperasi Syariah akan meningkat, dengan asumsi citra merek dan lokasi tetap. Nilai koefisien regresi lokasi memiliki nilai 0,182 hal ini berarti apabila lokasi mengalami perbaikan, maka keputusan menjadi anggota koperasi Syariah akan meningkat dengan asumsi citra merek dan kemudahan transaksi tetap.

\section{Pembahasan}

Pengaruh citra merek terhadap keputusan menjadi anggota Koperasi Syariah BMT BISMA

Citra merek tidak mendukung keputusan menjadi anggota Koperasi Syariah BMT BISMA karena anggota Koperasi Syariah BMT BISMA tidak terlalu melihat merek itu sebagai sesuatu yang penting bagi anggota hal ini dikarenakan mereka lebih melihat apa yang terkandung dalam merek tersebut atau manfaat yang ada pada merek tersebut.
Apapun nama digunakan pada jenis produk Koperasi Syariah BMT BISMA anggota tidak mempermasalahkan yang terpenting manfaat dari produk yang diberikan.

Hasil penelitian ini berbeda dengan penelitian yang dilakukan oleh Ubaida pada tahun 2020 dimana hasil penelitiannya menunjukan citra merek memiliki pengaruh yang signifikan $0,000<0,05$ dengan nilai tolerance $4,218>1,895$ hal ini dapat diartikan citra merek memiliki pengaruh yang signifikan terhadap minat menjadi anggota KSPPS BMT PETA cabang Tulungagung.

\section{Pengaruh kemudahan transaksi terhadap keputusan menjadi anggota Koperasi Syariah BMT BISMA}

Kemudahan transaksi mendukung terhadap keputusan menjadi anggota koperasi karena pelayanan yang ada di koperasi Syariah itu sangat diterima dan diapresiasi oleh anggota. Contohnya pelayanan angsuran dengan mendatangi langsung anggota satu persatu ke tempatnya, serta mendatangi langsung anggota untuk diberikan layanan perkoperasian.

Hasil penelitian ini memiliki kesesuaian dengan penelitian yang dilakukan oleh Fitrianto pada tahun 2018 dimana pada penelitian terdahulu menunjukan kemudahan persyaratan memiliki pengaruh yang signifikan terhadap keputusan seorang konsumen dalam mengajukan kredit di Koperasi Primkopabri Magetan.

\section{Pengaruh lokasi terhadap keputusan menjadi anggota Koperasi Syariah BMT BISMA}

Lokasi mendukung terhadap keputusan menjadi anggota Koperasi Syariah BMT BISMA. Hal ini membuktikan Koperasi Syariah BMT BISMA, karena lokasi tersebut mudah untuk dijangkau dengan baik, serta dapat diakses dengan cepat dan mudah. 
Hasil penelitian ini sejalan dengan penelitian yang dilakukan oleh Kurnia (2019) dimana dalam hasil penelitiannya menjelaskan bahwa variabel lokasi memiliki pengaruh yang signifikan terhadap partisipasi anggota Koperasi Wanita Syariah Al Hidayah Plosokandang Tulungagung, berdasarkan hasil analisisnya pertimbangan seseorang berkaitan dengan lokasi biasanya dilihat dari jauh dekatnya lokasi koperasi dengan tempat tinggal anggotanya.

\section{KESIMPULAN DAN SARAN}

\section{Kesimpulan}

1. Citra merek tidak mendukung terhadap keputusan menjadi anggota Koperasi Syariah BMT BISMA.

2. Kemudahan transaksi mendukung terhadap keputusan menjadi anggota Koperasi Syariah BMT BISMA.

3. Lokasi mendukung terhadap keputusan menjadi anggota Koperasi Syariah BMT BISMA.

\section{Saran}

1. Kopereasi Syariah BMT BISMA harus memperhatikan kemudahan transaksi yang dilakukan kepada semua anggotanya baik dalam pelayanan tabungan, pembiayaan, jasa, maupun program sosial. Sehingga semakin banyak menarik pihak-pikah lain selain anggota untuk menjadi anggota di Koperasi Syariah BMT BISMA dan ini juga akan meningkatkan loyalitas yang sudah ada.

2. Koperasi Syariah BMT BISMA dapat mempertahankan lokasi yang ada karena lokasi ini dianggap sangan baik bagi mereka (anggota) dalam hal kemampuan akses lokasi, visibilitas tempat parkir dan lainya, telah memerikan dampak manfaat bagi anggota Koperasi Syariah BMT BISMA.

\section{DAFTAR PUSTAKA}

Andy. Jumlah Anggota Koperasi Syariah BMT BISMA, February 17, 2020.

Afandi, Muhammad Anif dan Amin, Muhammad. "Determinan Konsumsi Pada Negara Mayoritas Berpenduduk Muslim Dan Non Muslim: Studi Kasus Indonesia Dan Singapura." Journal of Economics and Business Aseanomics (JEBA) 3(1) (June 2018). Harahap, Dedy Ansari. "Analisis FaktorFaktor Yang Mempengaruhi Keputusan Pembelian Konsumen Di Pajak USU (PAJUS) Medan.” Jurnal Keuangan Dan Bisnis 7(3) (November 2015).

Hardani, dkk. Metode Penelitian Kualitatif \& Kuantitatif. Yogyakarta: CV. Pustaka Ilmu Group, 2020.

Koperasi Syariah Benteng Mikro Indonesia. "Koperasi Syariah Benteng Mikro Indonesia," March 31, 2021. https://kopsyahbmi.co.id/.

Lestari, Niken Ayu dan Iriani, Sri Setyo. "Pengaruh Kepercayaan Dan Kemudahan Transaksi Terhadap Keputusan Pembelian Secara Online Pada Situs Mataharimall.Com." Jurnal Ilmu Manajemen 6(1) (2018).

Marendra, I Gede. "Pengarur Bauran Pemasaran (Produk, Harga, Lokasi Dan Promosi) Terhadap Keputusan Pembelian Konsumen Di Minimarket (Alfamart Atau Indomart) (Studi Kasus Di Universitas Pamulang)." Jurnal Pemasaran Kompertitif 1(3) (April 2018).

Nafiah, Zumrotun. "Pengaruh Pengetahuan Masyarakat Tenang Lembaga Keuangan Syariah Dan Tingkat Religiusitas Terhadap Keputusan Menjadi Anggota BMT Yaummi Fatimah Pati Cabang Juwana." Skripsi, Fakultas Ekonomi dan Bisnis Islam Universitas Islam Negeri Walisongo, 2018. 
Nuri, Ria Shihiyyati. "Faktor-Faktor Yang Memengaruhi Minat Peserta Asuransi Pada Produk Takaful Dana Pendidikan (Studi Kasus Pada PT. Asuransi Takaful Keluarga Representative Office Tangerang Banten)." Skripsi, Program Studi Ekonomi Syariah Sekolah Tinggi Ekonomi Syariah (STES) Islamic Village, 2020.

Pardede, Ratlan dan Haryadi, Tarcicius Yudi. "Pengaruh Persepsi Harga Dan Kualitas Produk Terhadap Keputusan Pembeliain Konsumen Yang Dimediasi Keputusan Konsumen." Journal of Business \& Applied Management 10(1) (2017).

Saripah, Putri, Adriyanti Agustina dan Darwin, Ranti. "Pengaruh Kepercayaan, Persepsi Kebermanfaatan, Persepsi Risiko Dan Kepuasan Wajib Pajak Terhadap Penggunaan e-Filling Bagi Wajib Pajak Orang Pribadi Di KPP Pratama Pekanbaru Tampan Tahun 2015." Jurnal Akuntansi \& Ekonomika 6(2) (2016).

Ulfah, Cut Dilam Chalida. "Analisis Pengaruh Citra Merek, Periiklanan Dan Persepsi Terhadap Keputusan Nasabah Memilih Bank Syariah (Studi Pada PT. Bank Syariah Mandiri KC Meulaboh)." Skripsi, Fakultas Ekonomi dan Bisnis Islam Universitas Islam Negeri Ar-Raniry, 2018. 